\title{
PENYULUHAN CARA MENGHADAPI GENERASI MILLENIAL BEKERJASAMA DENGAN SEKOLAH, GEREJA DAN RADIO
}

\author{
Krishervina Rani Lidiawati ${ }^{1}$ \\ ${ }^{1}$ Fakultas Psikologi Universitas Pelita Harapan \\ krishervina.lidiawati@uph.edu
}

\begin{abstract}
Abstrak
Penggunaan internet sudah meluas termasuk pada anak dan remaja yang dapat berdampak baik maupun buruk bagi perkembangan anak. Oleh karena itu diperlukan adanya informasi tentang pola asuh yang tepat untuk menghadapi generasi milenial yang tidak lepas dari penggunaan internet. Pola asuh orang tua berperan dalam perkembangan anak agar bertumbuh-kembang secara sehat baik fisik, kognitif dan psikososial. Banyaknya anak yang sulit melepaskan gawai (gadget) dan berdampak pada emosi, perilaku maupun prestasi di sekolah membuat orang tua kebingungan dalam menghadapi anak generasi millennial. Permasalahan ini mendorong untuk melakukan Pengabdian Kepada Masyarakat (PKM) dengan metode penyuluhan bagi orang tua yang dilakukan di sekolah, gereja dan radio. PKM ini bekerjasama dengan sekolah, gereja dan radio. Penyuluhan pertama dilakukan untuk orang tua murid Sekolah TK Budaya. Penyuluhan kedua dilakukan untuk orang tua dan guru sekolah minggu Gereja Charismatic Worship Service (CWS) Senen,di Jakarta. Penyuluhan ketiga, bekerjasama dengan Yayasan Busur Emas (YBE) dalam program Parenting with heart disiarkan melalui radio heartline 100.6 FM. Hal ini dilakukan agar informasi dapat diterima secara lebih luas sehingga orang tua dapat menghadapi anak generasi milenial yang fasih dalam penggunaan teknologi digital. Berdasarkan penyuluhan yang telah dilakukan di sekolah dan gereja lebih dari $50 \%$ orang tua telah mengetahui dampak negatif dari penggunaan gawai yang berlebihan namun belum memiliki aturan penggunaan gawai di rumah.
\end{abstract}

Kata Kunci : pola asuh, generasi millenial, gawai

\section{PENDAHULUAN}

Realita kemajuan teknologi yang sangat pesat dan penggunaan internet yang semakin meluas tidak dapat dihindari dan dihentikan. Perkembangan teknologi ini memengaruhi kehidupan manusia baik secara sosial maupun budaya dalam masyarakat. Hal ini terutama dalam pemakaian internet pada anak dan remaja yang tentunya memiliki dampak positif dan negatif bagi perkembangan anak. Berdasarkan penelitian, penggunaan gawai pada anak dapat dikategorikan menjadi tiga yaitu sebagai sarana untuk berkomunikasi, bermain, dan memperoleh informasi (Ihmeideh \& Shawareb, 2014). Penggunaan gawai ini tentu dipengaruhi adanya bimbingan dan arahan dari orang tua. Artinya peran 
orang tua penting dalam memberikan arahan terkait batasan waktu dan fungsi penggunaan gawai. Hal ini terkait dengan dampak yang terjadi akibat tidak adanya batasan waktu dalam penggunaan internet yaitu kecanduan, prestasi di sekolah menurun, minat terbatas dalam penggunaan internet, kemampuan sosial bermasalah dan sulit untuk bekerjasama (Chou \& Lee, 2017).

Berbagai penelitian juga telah menunjukkan dampak buruk ketika anak menggunakan gawai secara berlebihan hingga mengalami adiksi atau kecanduan (Kanan, Arokiasamy, \& Ismail, 2018). Jumlah anak yang mengalami kecanduan dari tahun ke tahun semakin meningkat dan sulit dikendalikan oleh orang tua. Hal ini terkait dengan seberapa lama anak telah mengenal dan menggunakan gawai tanpa bimbingan orang tua bahkan dibiarkan (Cetinkaya, 2019).

Berdasarkan data OECD 2015, terdapat 22\% remaja tercatat menggunakan internet lebih dari 6 jam per hari untuk online, $18 \%$ menggunakan 4-6 jam, $26 \%$ 2-4 jam dan $18 \%$ 1-2 jam. Selain itu waktu rata-rata penggunaan gawai meningkat dari 59 menit menjadi 65 menit (Tur-Porcar, 2017). Penggunaan internet pada remaja seharusnya berhubungan dengan kegiatan akademik seperti mencari informasi terkait tugas sekolah, dan sarana berkomunikasi dengan teman-teman sebaya. Namun banyak remaja saat ini menggunakan internet dengan sembarangan seperti untuk melecehkan orang lain, penyebaran informasi berbau pornografi, dan menyebarkan informasi yang belum diketahui kebenarannya (Sánchez-Valle, de-Frutos-Torres, \& Vázquez-Barrio, 2017).

Setiap orang tua memiliki prinsip yang berbedabeda dalam mendidik anak-anak mereka. Pola didik inilah yang dikenal dengan pola asuh terhadap anak. Kebanyakan orang tua menerapkan pola didik berdasarkan dari pengalaman generasi sebelumnya. Misalnya kepercayaan dan pendidikan keluarga yang dipelajari akan diterapkan kepada anak mereka. Namun patut disadari bahwa perkembangan anak dan karakteristik anak berbeda-beda sehingga cara menghadapi mereka pun tentu tidak sama.

Bagi keluarga yang modern mungkin akan mencari informasi dari berbagai sumber seperti situs keluarga, cara mendidik anak, atau pun berkonsultasi langsung dengan orang yang ahli dibidang parenting (Lee \& Chou, 2019). Beberapa orang sudah sadar untuk mengikuti kelas parenting di sekolah atau mengikuti secara mandiri seminar yang berkaitan dengan "parenting". Namun demikian masih banyak juga orang tua yang belum menyadari pentingnya mendidik anak dengan baik. Hal ini dipengaruhi berbagai faktor seperti budaya, pendidikan, status sosial ekonomi dan karakteristik seseorang. Salah satu faktor yang mempengaruhi suksesnya pola asuh adalah tingkat pendidikan orang tua. Semakin tinggi pendidikan orang tua maka orang tua menyadari pengasuhan yang baik diperoleh dengan terus belajar dan mengembangkan diri. Mereka belajar baik dari buku ataupun pihak profesional (Lee \& Chou, 2019).

Generasi millennial diartikan sebagai generasi yang kehidupannya tidak bisa terlepas dari teknologi, internet dan kecanggihan artificial intelligence. Namun seharusnya anak millennial adalah anak-anak yang terlahir dari tahun 1981 - 1995, artinya millennial paling muda saat ini sudah berusia 20 tahunan. Setelah generasi millennial atau yang dikenal dengan istilah generasi $\mathrm{Y}$ adalah generasi generasi Z. Generasi Z ini lebih mahir, fasih dan mahir dalam penggunaan gawai. Mereka terlahir setelah tahun 1995, saat ini usia sekolah dan sedang aktif dalam penggunaan internet melalui gawai yang mereka miliki (Persada, Miraja, \& Nadlifatin, 2019).

Namun dikarenakan masyarakat masih menganggap bahwa ada kemiripin antara generasi $\mathrm{Y}$ dan $\mathrm{Z}$ mereka menyebut generasi yang melek teknologi disebut millennial. Meski masing-masing generasi memiliki ciri khas dan perbedaan yang akan memengaruhi hidup mereka. Peran orang tua dalam menghadapi mereka tentu tidak mudah maka diperlukan informasi yang membantu orang tua mengatasi permasalahan-permasalahan akibat perbedaan generasi yang mungkin menyebabkan perbedaan pandangan juga.

Adanya perbedaan generasi ini membuat tantangan hidup pun relatif berbeda. Misalnya, generasi milenial harus berhadapan dengan pengendalian diri terhadap paparan informasi dunia maya. Pada zaman orang tua mungkin hal ini bukan menjadi kendala atau belum terlalu terpengaruh oleh gawai, namun anak-anak yang terlahir diatas tahun 2000 sulit untuk dilepaskan. Pemahaman perbedaan generasi ini membantu orang tua untuk lebih bijak dalam menanggapi kemajuan teknologi yang tidak dapat dihentikan namun orang tua perlu belajar untuk bisa memberikan arahan kepada anak agar mampu menjadi pengguna gawai bukan diperalat oleh gawai.

$$
\text { Pendidikan }
$$


Oleh karena itu diperlukan pemahaman tentang cara didik yang tepat. Pada hakekatnya mengasuh anak perlu adanya adanya kasih sayang, kehangatan dan juga kontrol, meliputi pengawasan, arahan, tuntutan dari orang tua (Tur-Porcar, 2017). Adanya kontrol dan pengawasan orang tua berhubungan dengan pencapaian prestasi anak dan cara ia menghadapi lingkungan sosial serta masa depannya. Di sisi lain, orang tua yang memiliki kontrol terlalu berlebihan membuat pengalaman yang menyakitkan secara emosional, perasaan tidak aman dan merasa diabaikan atau terisolasi dari kehidupan sehariharinya. Hal ini berdampak pada individu menjadi merasa kewalahan dan kehilangan kontrol dan tidak mampu menanggung resiko atau bertanggung jawab (Cetinkaya, 2019) .

Berdasarkan dua dimensi kontrol dan kehangatan maka terbagi menjadi empat tipe pola asuh yaitu autoritatif, otoriter, pengabaian dan permisif. Autoritatif atau pola asuh yang berkompeten dan tepat untuk diterapkan adalah pola asuh yang memberikan kasih sayang, kehangatan, dukungan dan komunikasi yang baik disertai dengan pendisiplinan yang tepat. Orang tua memberikan kasih sayang dan tuntutan secara seimbang kepada anaknya dan diberikan secara konsisten.

Orang tua yang autoritatif cenderung mendorong anak berkomunikasi dua arah yang bertujuan agar tercipta kesejahteraan mental di dalam keluarga tersebut. Sebaliknya, pola asuh otoriter memiliki karakteristik, kontrol orang tua tinggi namun sedikit kehangatan atau dukungan, kasih sayang orang tua sedikit. Orang tua otoriter banyak memberikan batasan, tuntutan kepada anak sehingga membuat anak cenderung kaku dan kurang adaptif di lingkungan sosial. Ada pula tipe pola asuh yang tidak terlibat atau mengabaikan yaitu memiliki karakteristik kurang memiliki kontrol dan kurang hangat juga. Pola asuh yang keempat yaitu permisif. Tipe permisif adalah orang tua yang memiliki karakteristik kontrol rendah namun kasih sayang dan kehangatan relatif tinggi sehingga cenderung memenuhi keinginan anak tanpa batasan (Kokkinos, Antoniadou, Asdre, \& Voulgaridou, 2016; Mousavi, Low, \& Hashim, 2016; Tur-Porcar, 2017).

Berdasarkan hal diatas maka dapat disimpulkan bahwa informasi tentang pola asuh yang tepat bagi orang tua untuk mampu menghadapi anak-anak di generasi millennial masih dibutuhkan. Hal ini terutama orang tua yang memiliki anak usia sekolah dan remaja. Penyebaran informasi ini pun dapat dilakukan lewat penyuluhan di sekolah, gereja dan radio.

\section{METODE}

Penyuluhan ini dilakukan dalam bentuk seminar secara langsung kepada orang tua di sekolah, gereja serta siaran radio. Penyuluhan pertama diberikan di Sekolah Budaya kepada orang tua murid TK Budaya dalam bentuk seminar. Penyuluhan tersebut dilaksanakan pada hari Kamis, 14 Maret 2019. Tema yang dibawakan "Pengaruh gadget pada anak usia dini" diberikan dalam satu sesi berdurasi 90 menit. Pada akhir sesi diberikan kesempatan untuk diskusi dan tanya jawab. Jumlah peserta adalah 69 orang tua. Penyuluhan yang kedua dilakukan pada Sabtu, 13 April 2019 di Gereja CWS. Penyuluhan ini diselenggarakan dalam dua sesi, sesi pertama bertema "Parenting with heart", sesi kedua bertema "How to deal with millennial generation". Adapun jumlah peserta yang mengikuti seminar ini adalah 75 orang yang terdiri dari orang tua murid dan guru sekolah minggu di gereja tersebut. Masingmasing sesi diberikan waktu 120 menit yang terbagi 90 menit materi dan 30 menit untuk sesi tanya jawab.

Pada awal sesi pertama, orang tua diberikan kuesioner tentang tipe pola asuh yang mereka terapkan kepada anak-anak mereka. Pada akhir sesi pertama diberikan sesi tanya jawab yang berlangsung selama 30 menit. Pada sesi kedua, orang tua diminta untuk menuliskan pertanyaan berkaitan dengan tema di flip chart yang tersedia sehingga membantu pemateri untuk dapat lebih fokus pada permasalahan yang sering muncul di komunitas tersebut. Dan di akhir sesi dua maka pemateri memberikan kata kunci dan memberikan kesempatan untuk tanya jawab kembali selama 30 menit. Berbeda dengan penyuluhan yang secara langsung, penyuluhan ketiga dilakukan melalui penyiaran radio Heartline (100.6 FM) pada program "Parenting with heart" selama 60 menit. Tema yang dibawakan adalah "How to deal with i-Generation?", pada tanggal 27 April 2019. Dalam siaran radio ini terbagi empat bagian yaitu latar belakang, isi materi, tanya jawab dan kesimpulan. Adapun tanya jawab melalui media whatshap dan telepon secara langsung.

$$
\text { Pendidikan }
$$




\section{HASIL DAN PEMBAHASAN}

\section{Pola asuh orang tua yang tepat dalam menghadapi generasi millennial}

Setiap penyuluhan yang telah dilaksanakan menekankan pengasuhan orang tua kepada anak secara tepat agar perkembangan anak dapat sesuai potensi. Perkembangan anak meliputi perkembangan fisik, kognitif dan psikosial (Papalia \& Martorell, 2018). Artinya orang tua perlu memahami adanya hambatan yang ditimbulkan ketika anak tidak berkembang seperti anak seusianya. Oleh karena itu, orang tua perlu mendapatkan informasi tentang tahap dan tugas perkembangan anak sehingga dapat mermahami kendala atau perilaku yang seharusnya dimunculkan oleh anak. Selain itu, memahami tahap perkembangan membantu orang tua untuk menyadari adanya jarak usia atau perbedaan generasi antara orang tua dengan anak, yang dapat mempengaruhi perbedaan situasi atau masalah yang timbul.

Adapun berbagai permasalahan tentang tahap perkembangan dan perbedaan generasi dapat diminimalisasi ketika orang tua telah menetapkan pola asuh yang tepat. Pada PKM ini memaparkan definisi pola asuh yaitu merupakan pengasuhan orang tua, cara mendidik orang tua kepada anaknya. Adapun dua dimensi dalam pola asuh yaitu kontrol dan kehangatan (Miller \& Speirs Neumeister, 2017). Penekanan pada pola asuh autoritatif dibandingkan tipe pola asuh yang lain. Orang tua harus tetap memberikan pengawasan, bimbingan dan arahan kepada anak-anak mereka. Namun di sisi lain, orang tua juga dituntut untuk dapat memberikan kasih sayang kepada mereka bisa berupa pujian, pelukan, apresiasi dan penguatan yang lainnya atas usaha mereka. Jika orang tua dapat berperan secara seimbang dalam memberikan kontrol dan kehangatan maka seharusnya komunikasi dapat terjalin dengan baik bahkan meski terjadi perbedaan generasi.

Orang tua juga diberikan wawasan mengenai perbedaan generasi $\mathrm{X}, \mathrm{Y}, \mathrm{Z}$ sehingga dapat memahami adanya perbedaan jarak usia dengan anaknya yang memungkinkan banyak perbedaan budaya. Sekaligus penyebutan generasi millennial menjadi kurang tepat dikarenakan anak-anak yang dihadapi sudah termasuk generasi $\mathrm{Z}$ yaitu generasi yang fasih dan mahir dalam penggunaan internet.
Misalnya budaya berkomunikasi, dahulu harus bertemu langsung saat ini dapat berkomunikasi melalui gawai yang dimiliki. Namun bukan berarti komunikasi langsung tidak penting, justru orang tua perlu mengajarkan ketrampilan sosial, cara bersosialisasi dan berkomunikasi secara langsung kepada generasi yang aktif dengan teknologi digital.

Penyuluhan pada PKM ini terbagi menjadi tiga tempat dan pada waktu yang berbeda. Adapun pelaksanaan dapat dilihat sebagai berikut ini

Tabel 1. Jadwal kegiatan

\begin{tabular}{llc}
\hline No & \multicolumn{1}{c}{ Tempat } & Waktu \\
\hline 1 & TK Budaya Jakarta & 90 menit \\
2 & Gereja CWS Senen & $2 \times 120$ menit \\
3 & lio heartline (100.6 FM) & 60 menit \\
\hline
\end{tabular}

Pada penyuluhan pertama di TK budaya, orang tua belum memahami kebutuhan, tuntutan tahap perkembangan anak mereka sehingga masih dibutuhkan informasi cara mengasuh yang tepat. Sedangkan untuk penyuluhan di gereja, beberapa orang tua sudah memiliki pengetahuan dan menerapkan namun masih banyak yang belum memahami perbedaan tugas perkembangan sehingga penerapan pola asuh pun masih sesuai pengalaman pribadi atau pola asuh yang pernah mereka alami sewaktu kecil.

Peserta merupakan orang tua yang memiliki anak di usia prasekolah yaitu usia 4-6 tahun. Usia ini seharusnya hanya boleh terpapar gawai atau menggunakan interet sebatas hiburan atau belajar bahasa dan bukan sebagai kebutuhan untuk mengerjakan tugas sekolah seperti anak usia sekolah lainnya. Orang tua perlu menyadari memperhatikan kesehatan fisik, kognitif dan psikososial anak akibat pemakaian gawai lebih dari tiga jam sehari. WHO dan asosiasi dokter anak telah menetapkan bahwa anak usia dibawah dua tahun tidak boleh terpapar gawai, sedangkan usia diatas 2 tahun - 12 tahun hanya boleh terpapar 30 menit. Hal ini demi kesehatan fisik seperti mata dan cukup waktu tidur yang tentunya berdampak pada perkembangan dan kesehatan anak (Bartau-Rojas, Aierbe-Barandiaran, \& Oregui-González, 2018).

Beberapa dari peserta menerapkan pola asuh permisif yaitu memberikan kasih sayang yang berlebihan namun pengawasan dan arahannya sangat minim. Hal ini berdampak pada keinginan anak yang

$$
\text { Pendidikan }
$$


kerapkali dituruti dan mengakibatkan anak manja serta tidak mandiri. Salah satu contohnya, anak meminta gawai dan bermain tanpa batasan dengan alasan jika gawai diminta maka anak akan menangis kencang dan marah. Hal tersebut merupakan salah satu dampak dari penerapan pola asuh yang diterapkan kurang tepat sehingga memberi dampak pada kepribadian anak juga.

Pada penyuluhan kedua di Gereja CWS, orang tua dan guru sekolah minggu memiliki antusiasme yang tinggi untuk bertanya tentang cara mendidik anak yang baik dan tepat. Berdasarkan kuesioner parenting yang telah diisi, 29 peserta memilih pernyataan yang menggambarkan orang tua tipe autoriratif, 25 peserta sebagai orang tua permisif, 21 peserta memilih pernyataan sebagai orang tua otoriter dan satu peserta yang memilih pernyataan sebagai orang tua yang mengabaikan. Hal tersebut menunjukkan bahwa $38 \%$ orang tua dan guru sekolah minggu telah menyadari cara memperlakukan anak-anak mereka, namun selebihnya hanya berdasarkan pengalaman terdahulu. Orang tua memberikan apa yang diinginkan anak tanpa memberikan batasan dan arahan terutama dalam penggunaan gawai.

Peserta dalam seminar ini menunjukkan rasa ingin tau yang besar seperti aktif bertanya dan berpartisipasi dalam kegiatan penyuluhan ini. Peserta diminta untuk menuliskan perilaku anak-anak mereka yang sulit di ubah dan kebiasaan perilaku orang tua dalam menyelesaikan masalah. Lebih dari $50 \%$ peserta hanya mengandalkan pengalaman dari generasi sebelumnya dan kurang memperhatikan cara mendidik anak disesuaikan dengan perkembangan anak dan perbedaan generasi. Sesi pertama memberikan wawasan tentang prinsip pola asuh yaitu harus memiliki kekompakan dan konsisten dalam memberikan kehangatan dan kontrol kepada anak mereka. Artinya pada sesi pertama menekankan agar orang tua dapat menerapkan pola asuh autoritatif dibandingkan pola asuh yang lainnya serta memberi informasi dampak dari pola asuh yang tidak tepat.

Pada sesi kedua, penjelasan mengenai cara menghadapi generasi millennial yang didefinisikan dengan generasi yang melek teknologi. Selain itu pentingnya memahami adanya perbedaan generasi antara orang tua dengan anak. Hal ini membantu orang tua untuk mencari solusi yang tepat ketika menghadapi generasi yang tidak dapat dipisahkan dengan internet namun jangan sampai anak-anak mereka mengalami kecanduan. Peserta memahami pentingnya untuk memiliki peraturan di rumah dan tetap memberikan dorongan kepada anak yang telah berusaha bukan karena hasil yang mereka peroleh. Orang tua lebih memahami bahwa adanya komunikasi dua arah membantu menyelesaikan masalah dengan generasi millennial yang serba cepat dan terbuka terhadap informasi. Anak-anak lebih baik mendapat informasi dan arahan dari orang tua daripada mencari informasi secara mandiri tanpa adanya pengawasan dan kontrol dari orang tua. Orang tua juga perlu membuka diri untuk menambah pengetahuan sehingga bisa mengikuti perkembangan lingkungan sosial yang dihadapi anak-anak mereka. Misalnya media sosial yang biasa mereka gunakan, kegunaannya dan pertemanan di dunia maya. Ketika orang tua tidak mengetahui perkembangan dunia sosial maka menghambat pembicaraan karena dianggap orang tua tidak update.

\section{Kesadaran peran orang tua dalam membatasi penggunaan gawai}

Berdasarkan penyuluhan di Sekolah TK Budaya, para orang tua mengalami kesulitan dalam memberikan arahan dan bimbingan terkait batasan waktu yang boleh digunakan dalam menggunakan gawai. Selain batasan, beberapa orang tua belum memahami dampak dari penggunaan gawai secara berlebihan pada anak usia 4-6 tahun. Beberapa dari orang tua mengeluhkan anak mereka sudah sulit untuk dilarang dan melebihi batas waktu yang telah disepakati bersama.

Orang tua percaya bahwa ketika anak menggunakan internet banyak pengaruh buruk seperti perilaku agresi, pornografi, kecanduan narkoba dan kecanduan game online. Kekhawatiran ini sama-sama dimiliki oleh orang tua dari anak lakilaki ataupun perempuan (Sánchez-Valle et al., 2017). Ketakutan yang lain adalah anak menjadi belajar kata-kata yang tidak sopan dan lupa untuk bermain bersama dengan teman sebaya. Disisi lain orang tua juga memiliki pemikiran positif seperti anak mampu belajar kritis, mereka mudah belajar bahasa, lebih mudah mendapatkan informasi sehingga dapat menyelesaikan tugas, dan tidak ketinggalan dengan anak sebayanya. 
Berdasarkan hal tersebut dapat disimpulkan bahwa orang tua perlu menyadari bahwa penggunaan internet dengan tepat berguna bagi anaknya dan tidak akan menghambat perkembangan tetapi justru membantu perkembangan anak misalnya dalam belajar bahasa. Anak dapat diajarkan bahasa asing sejak dini dan lebih fasih namun penggunaan internet berlebih membuat komunikasi satu arah sehingga berdampak pada ketrampilan sosial yang kurang terhadap teman sebaya atau bahkan dapat menghambat kemampuan bicara pada anak dibawah 3 tahun. Demikian pula orang tua yang terlalu membebaskan anak dalam menggunakan internet maka dampak buruk yang dikhawatirkan dapat terjadi.

Hal ini juga terjadi pada orang tua di gereja CWS Senin, dari 70 peserta, hanya $10 \%$ yang sudah menerapkan aturan pembatasan pemakaian gawai dan secara konsisten memberikan arahan. Sedangkan lebih banyak orang tua yang hanya sesekali mengingatkan namun anak tidak menerima konsekuensi ketika ia tidak melakukan arahan dari orang tua. Orang tua sudah sadar bahwa gawai mempengaruhi perkembangan anak namun masih banyak dari orang tua kurang memahami fungsi gawai yang tidak sesuai dengan umur anaknya. Misalnya anaknya masih dibawah lima tahun. Anakanak mereka dibiarkan terlalu lama pasif dan kurang berinteraksi dua arah. Hal ini tentu tidak sesuai dengan perkembangan anak. Usia 0-2 tahun seharusnya anak berada pada tahap perkembangan kognitif sensori motorik. Artinya anak belajar dari lima indera mereka untuk mendapatkan informasi yang baru yaitu dengan melihat, mendengar, meraba, mencium dan merasakan. Hal ini berarti perlu adanya berbagai stimulus sehingga anak mereka berkembang dengan baik.

Selain itu, banyak dari orang tua yang anaknya masih usia 2-7 tahun tidak memberikan batasan yang jelas dalam pemakaian gawai. Hal ini berdasarkan pertanyaan yang diajukan pada saat penyuluhan berlangsung. Sebagian besar orang tua membiarkan dan bahkan menjadikan gawai sebagai sarana agar anak duduk diam.

\section{KESIMPULAN}

Informasi tentang cara mengasuh yang tepat dalam menghadapi generasi millennial dibutuhkan oleh orang tua sehingga dapat membantu mencari pemecahan masalah yang dihadapi. Salah satu kesulitan orang tua di zaman internet yang meluas ini adalah menerapkan pola asuh yang konsisten dan memberikan batasan waktu yang tepat bagi anak. Hal ini dapat terjadi akibat kurangnya informasi pada orang tua. Selain itu, orang tua juga belum memahami dampak yang ditimbulkan akibat pengasuhan yang tidak tepat pada anak-anak mereka. Kendala yang lain adalah orang tua kurang memiliki kesadaran untuk menambah informasi tentang cara mendidik anak melalui buku parenting atau meminta pertolongan pihak profesional. Selain itu, orang tua perlu menerima perbedaan jarak usia dan generasi sehingga membutuhkan usaha untuk terus belajar cara berkomunikasi dua arah dengan anak-anak mereka.

\section{UCAPAN TERIMAKASIH}

Terimakasih kepada Universitas Pelita Harapan, TK Budaya, Gereja CWS, Yayasan Busur Emas yang bekerjasama dengan heartline radio (100.6 FM) yang telah memberikan kesempatan kepada saya sehingga penyuluhan kepada orang tua tentang cara pengasuhan yang tepat dapat terselenggara dengan baik. Terimakasih juga saya ucapkan kepada orangorang terdekat saya yang telah memberikan ide dan saran sehingga saya memiliki keberanian untuk memberikan materi cara mengasuh anak baik di sekolah, gereja dan radio hingga saat ini.

\section{REFERENSI}

Bartau-Rojas, I., Aierbe-Barandiaran, A., \& OreguiGonzález, E. (2018). Parental mediation of the Internet use of Primary students: Beliefs, strategies and difficulties. Comunicar, 26(54), 71-79. https://doi.org/10.3916/C54-2018-07

Cetinkaya, L. (2019). The relationship between perceived parental control and internet addiction: A cross-sectional study among adolescents. Contemporary Educational Technology, 10(1), 55-74. https://doi.org/10.30935/cet.512531

Chou, C., \& Lee, Y. H. (2017). The Moderating Effects of Internet Parenting Styles on the

$$
\text { Pendidikan }
$$


Relationship Between Internet Parenting Behavior, Internet Expectancy, and Internet Addiction Tendency. Asia-Pacific Education Researcher, 26(3-4), 137-146. https://doi.org/10.1007/s40299-017-0334-5

Ihmeideh, F. M., \& Shawareb, A. A. (2014). The association between internet parenting styles and childrens use of the internet at home. Journal of Research in Childhood Education, 28(4), 411-425. https://doi.org/10.1080/02568543.2014.94472 3

Kanan, N., Arokiasamy, L., \& Ismail, M. R. bin. (2018). A study on Parenting Styles and Parental Attachment in Overcoming Internet Addiction among Children. SHS Web of Conferences, 56(2), 02002. https://doi.org/10.1051/shsconf/20185602002

Kokkinos, C. M., Antoniadou, N., Asdre, A., \& Voulgaridou, K. (2016). Parenting and Internet Behavior Predictors of Cyber-Bullying and Cyber-Victimization among Preadolescents. Deviant Behavior, 37(4), 439-455. https://doi.org/10.1080/01639625.2015.10600 87

Lee, H. C., \& Chou, M. J. (2019). The exploration of the sources of parenting beliefs in Taiwan. Revista de Cercetare Si Interventie Sociala, 65, 9-25. https://doi.org/10.33788/rcis.65.1

Miller, A. L., \& Speirs Neumeister, K. L. (2017). The Influence of Personality, Parenting Styles, and Perfectionism on Performance Goal Orientation in High Ability Students. Journal of Advanced Academics, 28(4), 313-344. https://doi.org/10.1177/1932202X17730567

Mousavi, S. E., Low, W. Y., \& Hashim, A. H. (2016). Perceived Parenting Styles and Cultural Influences in Adolescent's Anxiety: A CrossCultural Comparison. Journal of Child and Family Studies, 25(7), 2102-2110. https://doi.org/10.1007/s10826-016-0393-x

Papalia, D.E \& Martorell, G. (2015). Experience Human Development. New York: McGrawHill

Persada, S. F., Miraja, B. A., \& Nadlifatin, R. (2019).
Understanding the generation $\mathrm{z}$ behavior on $\mathrm{D}$ learning: A Unified Theory of Acceptance and Use of Technology (UTAUT) approach. International Journal of Emerging Technologies in Learning, 14(5), 20-33. https://doi.org/10.3991/ijet.v14i05.9993

Sánchez-Valle, M., de-Frutos-Torres, B., \& Vázquez-Barrio, T. (2017). Parent's influence on acquiring critical internet skills. Comunicar, 25(53), 103-111. https://doi.org/10.3916/C532017-10

Tur-Porcar, A. (2017). Parenting styles and Internet use. Psychology and Marketing, 34(11), 10161022. https://doi.org/10.1002/mar.21040 